\title{
Fetal calf serum drought hits cell culture laboratories
}

CELL culture laboratories throughout the world have been hit by their own fuel crisis - a shortage of fetal calf serum, the magic component of the media in which many biologists grow their cells. Supply has become uncertain, and the price has escalated; in the UK it has doubled in the past year and is now pushing $£ 100$ a litre.

Scientists are now exploring alternative ways of growing cells. At the very least they are in for a lot of trial and error, and time consuming work, as cells are weaned off fetal calf serum. Some projects will have to be abandoned.

Changes in world agricultural policies and practices lie behind the shortage, says $\mathrm{Mr}$ Tom Coutts, the managing director of Gibco Europe Ltd., which with Flow Laboratories, is the main distributor of fetal calf serum in Europe. He believes the overall supply will be bad for one or two years but may ease in the long term.

Flow was unable to supply any fetal calf serum at the end of April, and the company described the shortage as "very, very serious". In late April Gibco wrote to customers saying "severe shortages" would affect supply "for the foreseeable future . . . it is in our customers' interest to take every possible step to reduce their dependence on this product". Both companies hope the short term situation will be boosted by the start in April of the serum collection season in Australia and New Zealand, Europe's main sources of supply.

Fetal calf serum is a by-product of the beef industry. It is extracted by cardiac puncture when a cow brought to market for slaughter is found to be pregnant. $\mathrm{Mr}$ Coutts traces the current shortage back three years when beef prices were low, cattle were slaughtered rather than raised for the meat market, and calves, which would have become today's breeding stock, were lost. Now beef prices have risen and calves are being reared. Also, the US has lifted beef import quotas against Australia, making it even more profitable for Australian farmers to keep their calves.

Fetal calf serum is widely used by research institutes, hospitals, and universities for medical research, and by pharmaceutical companies in drug production. Its application includes use in diagnostic procedures, cancer research, and virology.

In the past the serum has been freely available, with just the occasional minor problem of supply. It has also been relatively inexpensive and extremely effective, curiously for reasons not yet understood. Its widespread introduction during the $1960 \mathrm{~s}$ meant an end to the practice of scientists undergoing a selfimposed 24-hour starvation and obtaining a pint of their own blood for use in the medium.

Dr John Birch of Searle Research and Development says that "a great mythology" surrounds fetal calf serum. Dr Eric Hall, an English scientist at Columbia University in New York, says: "Tissue culture work using fetal calf serum has got a bit out of hand. We have sloshed it around because it was cheap and available. Some work has been done just for fun. We need to rethink our priorities." Now many laboratories will have to stop using it.

The Imperial Cancer Research Fund (ICRF) in London, which has about 70 people in tissue culture work, replenishes its supplies monthly and is now receiving about half the fetal calf serum (75 litres a month) it needs to meet its planned research programme. ICRF scientists have been asked to halve the amount of serum they use in media, to $5 \%$.

University departments simply do not have the money to keep paying for the serum. Small laboratories are faced with a dilemma: either they pay high prices with the knowledge that they can successfully grow their cells, or they gamble with cheaper sera which may not give the desired results.

Professor Sydney Shall of the Biochemistry Department at Sussex University suggests that the number of places able to do tissue culture work will decrease. "It's a grave issue," he says. His cell lines are sensitive human cultures such as brain cells and they need $10 \%$ fetal calf serum. His department is rethinking its research programme.

Dr Colin Arlett of the Medical Research Council's Cell Mutation Unit, at Sussex, can provide an example. He is growing fibroblasts from patients suffering from ataxia telangectasia, a genetic disease. These cells are difficult to grow even on fetal calf serum and "if it becomes completely unavailable, or the price prohibitive, work on these cells will have to cease."

Cell biologists in Europe are no longer given the luxury of testing batches of fetal calf serum before purchase. They have been told by distributors to take what they are given or look for another source. Without testing, there is no guarantee that a particular batch of serum will support adequate growth of the cells being used.

"At least we have a buffer compared with smaller laboratories," Mr William House, manager of research services at
ICRF, said. "If a particular batch of fetal calf serum doesn't suit one person's cell lines, it can be used by someone else."

The attitudes and methods of biologists themselves may be contributing to the problem. Panic buying has occurred over the last 12 months says $\mathrm{Mr}$ Coutts. The demand is artificially high, fed by the rumours of the impending short supply. Unwillingness to try alternatives and over dependence on fetal calf serum may also be factors.

In searching for alternatives, the most popular solution is likely to be weaning the cells onto other sera. Indeed, some scientists claim that they predicted problems of supply of fetal calf serum and have successfully changed to other sera. Alternative sera are less costly and more readily available. However, there may also be some problems.

New born calf serum, asceptic calf serum, and horse serum will support the growth of some cells, although usually with poorer growth rates; and some primary cell lines may have an absolute requirement for fetal calf serum.

Another complicating factor is whether or not the properties of the cells will change. Once the cells are growing on other sera, partially completed projects face the possibility of a change in the cellular response to the treatment - such as irradiation or drugs - under investigation. Earlier experiments which used fetal calf serum may have to be repeated. Dr Hall has already reported such cellular changes in response to chemotherapeutic drugs.

Many scientists believe that the ideal solution to the dual problems of the supply of serum and the variability it causes in the growth of cells can be solved by the use of a totally defined or synthetic medium. Attempts over the last 20 years to identify the magic ingredient(s) in fetal calf serum have not been successful; the latest shortage may revive this work. Several cell lines already grow on a totally defined medium and the popularity of these cells is sure to increase.

A further question arising from the shortage is the effect it will have on the antivivisectionist movement which believes that biologists should turn to tissue culture in preference to research using animals. Legislation to encourage this development has been proposed in the UK and elsewhere in Europe. But biologists working with animals are unlikely to change to tissue culture if they see such problems with the supply of serum.

Ian Anderson

Ian Anderson is a freelance journalist 